\title{
Analysis of PV Array System with Buck-Boost Converter Using Perturb \& Observe Method
}

\author{
Jaya Shukla ${ }^{1}$, Dr. Jyoti Shrivastava ${ }^{2}$ \\ M.Tech (Power System), EE, SHIATS, Allahabad, India ${ }^{1}$ \\ Assistant Professor, EE, SHIATS, Allahabad, India ${ }^{2}$
}

\begin{abstract}
In this paper utilization of a buck-boost converter for control of photovoltaic power using Maximum Power Point Tracking (MPPT) control mechanism is presented. First the photovoltaic module is analyzed using MATLAB. For the main aim of the project is the buck -boost converter is to be used along with a Maximum Power Point Tracking control mechanism. The MPPT is responsible for extracting the maximum possible power from the photovoltaic and feed it to the load via the buck boost converter which steps up the voltage to required magnitude. The main aim will be to track the maximum power point of the photovoltaic module so that the maximum possible power can be extracted from the photovoltaic. The algorithms utilized for MPPT are generalized PO algorithms and are easy to model or use as a code. The algorithms are written in m files of MATLAB and utilized in simulation. Both the buck boost converter and the solar cell are modelled using Sim Power System blocks.
\end{abstract}

Keywords: MPPT, PV Array, Perturb and Observe (PO), Solar Energy, Buck Boost Converter.

\section{INTRODUCTION}

Crisis and environmental issues of non renewable energy resources are leading toward the renewable energy resources for the betterment of modern society. One of the most efficient renewable resources is solar energy. Solar energy is the most abundant resource on Earth, and is expected to become one of the primary energy supply resources in the future. There are many applications of solar energy in industrial, commercial, and military level [1]. In solar energy system PV generation system plays a vital role to produce electrical energy. But, PV generation systems have two major problems:-

1. The conversion efficiency of electric power generation is very low $(15 \%-20 \%)$ especially under low irradiation conditions.

2. The amount of electric power generated by solar arrays changes continuously with weather conditions.

So for the effective use of solar energy a power converter for maximal power point tracking (MPPT) and voltage or current regulation is inserted between the solar cell panel and the load to control power flow. This power converter directly affects the efficiency and performance of the solar power management system.

Moreover, the solar cell V-I characteristic is nonlinear and varies with irradiation and temperature. But, there is a unique point on the V-I or V-P curve, called the Maximum Power Point (MPP), at which the entire PV system (array, converter, etc...) operates with maximum efficiency and produces its maximum output power.

The location of the MPP is not known, but can be located, either through calculation models or by search algorithms. Therefore Maximum Power Point Tracking

(MPPT) techniques are needed to maintain the PV array's operating point at its MPP.

Now, in the current study, we focused on circuit simulation for the buck-boost converter-based MPPT system. The primary purpose is to establish a circuit
Simulation environment so that the performance of the buck-boost converters and MPPT systems can be evaluated quickly without the need of any hardware systems and instruments. The dynamic analyses of the buck-boost converter systems, buck-boost converter-based MPPT systems is developed using such algorithms to perform the MPPT function [3]. Circuit simulations for the complete buck-boost converter-based MPPT system are successfully verified in the MATLAB.

\section{PV CeLL}

\section{A. Photovoltaic Cell Theory}

The ability to generate electrical power by means of converting solar irradiation is called Photo voltaic. It first was characterized in 1839 by Becquerel when he observed two dissimilar materials would develop an electric potential when their junctions were illuminated with photons. Modern Photovoltaic (PV) cells use a semiconductor $\mathrm{p}-\mathrm{n}$ junction that after absorbing light energy, results in an increased population of charge carriers with a potential related to the band gap and also into cell heating which degrades the performance [2]. A typical solar cell consists of a $0.2 \mathrm{~mm}$ thick mono crystalline or polycrystalline silicon wafer having two layers that present different electrical properties enhanced by doping with impurities creating an electric field at the junction area. When sunlight impacts the solar cell the energy from the photons creates free charges that are separated by the electrical field, creating a potential so when a load is placed between the terminals a photo current $(I \mathrm{pv})$ is created. The most common material used in photocells today is silicon ( $\mathrm{Si}$ ) divided in mono crystalline, polycrystalline, and amorphous. The amount of energy they can deliver changes depending on the material of the cell and the incidence of sunlight. A simple PV cell from a modeling perspective is an ideal current source in parallel with an ideal diode as seen in Figure 2.1. The two 
parameters used to model and characterize a PV cell are: 3. A recombination factor related directly to the depletion the open circuit voltage ( $V o c$ ) and the short circuit current region of PV cells and to the amount of cells connected in (Isc ). The Voc is the maximum voltage which a solar cell series. Usually it's represented by a second diode in the can provide at zero current. The Isc is the maximum current which a solar cell can provide at zero voltage.

The output current from the PV cell can be found using the equation

$$
\mathbf{I}=\mathbf{I s c}-\mathbf{I d}
$$

where $I s c$ is the short circuit current that is equal to the photon generated current and $I d$ is the current shunted thought the intrinsic diode.

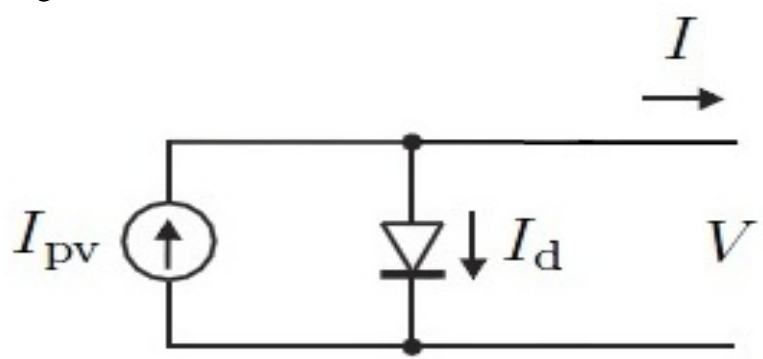

Figure 2.1. Ideal PV cell.

The diode current is given by Shockley's diode equation:

$$
\mathrm{I}_{\mathrm{d}}=\mathrm{I}_{0} *\left(\mathrm{e}^{\wedge \mathrm{qVd} / \mathrm{kT}-1)}\right.
$$

1. Io is the reverse saturation current of the diode

2. $q$ is the electro charge valued at $1.602 \times 10^{\wedge} 23 \mathrm{C}$

3. $V d$ is the diode's voltage

4. $k$ is Boltzmann's constant valued at $1.381 \times 10^{\wedge} 23 \mathrm{~J} / \mathrm{K}$

5. $\mathrm{T}$ is the junction temperature in Kelvin combining Equation (i) and Equation (ii) we then obtain:

$$
\mathrm{I}=\mathrm{I}_{\mathrm{sc}}-\mathrm{I}_{0} *\left(\mathrm{e}^{\wedge \mathrm{qV} / \mathrm{kT}-1)}\right.
$$

In this case $V$ is the voltage that exists across the PV cell and $I$ is the output current of the ideal circuit model.

A single solar cell typically produces only about $0.5 \mathrm{~V}$ so they need to be connected in series forming what is known as the PV Module. A PV panel is a collection of PV modules physically and electrically grouped together and finally a PV Array is a collection of PV panels. All three configurations follow the same basic modelling equations. The simple PV cell model neglects to take into consideration a series of parameters [3] that create a more accurate model represented in Figure 2.2:

1. The series resistance $(R s)$ : that accounts for any resistance in the current paths through the semiconductor material, the metal grid, contacts and currents controlling the system. This value also accounts for the loss associated with connecting a number of cells in series.

2. The parallel (shunt $R p$ ) resistance is loss associated with a slight leakage current through a parallel resistive path to the device. In most models it is neglected because its effect isn't as noticeable unless a large amount of cells are connected in parallel. where $\mathrm{n}$ also is sometimes described as a, being the ideality factor and its value is between 1 and 2 [4]. For the purposes of this research we have adopted the value proposed in [5] of 1.3.

The equivalent final circuit of the PV module is in Figure (2.3)

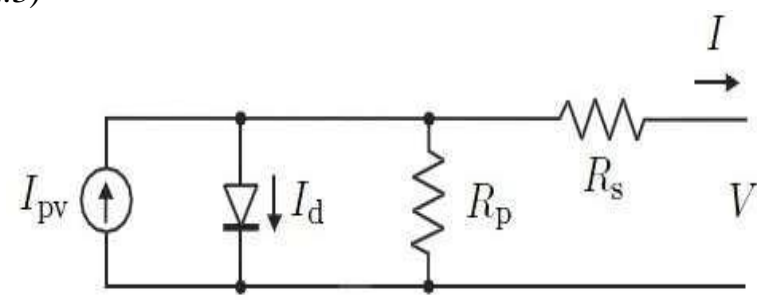

Figure 2.3. Equivalent circuit of PV cell.

The short circuit can be calculated at any given temperature using:

$$
\mathrm{I}_{\mathrm{sc} @ \mathrm{~T}}=\mathrm{I}_{\mathrm{sc} @ \operatorname{Tref}} *\left[1+\mathrm{K}_{\mathrm{i}}-\left(\mathrm{T}-\mathrm{T}_{\mathrm{ref}}\right)\right]
$$

Isc at the reference temperature is found on the datasheet, and refers to the temperature coefficient of Isc in percent change per degree. Both measurements are done under the standard irradiance of $1000 \mathrm{~W} / \mathrm{m} 2$. Normally the reference temperature is $25 \mathrm{C}$. The photon generated current also varies based on the irradiance $(\mathrm{G})$ according to the following equation:

$$
\mathrm{I}_{\mathrm{sc} @ \mathrm{G}}=\mathrm{I}_{\mathrm{sc} @ \mathrm{Gref}} *\left[\mathrm{G} / \mathrm{G}_{\mathrm{ref}}\right]
$$

Combining both equations and simplifying we then obtain a generic expression for the short circuit current. The assumption that Isc $\approx$ Ipv is generally used since the series resistance is low and the parallel resistance is high, leading then to:

$$
\mathrm{I}_{\mathrm{pv}}=\left(\mathrm{I}_{\mathrm{sc}}+\mathrm{K}_{\mathrm{i}} \Delta \mathrm{T}\right) \mathrm{G} / \mathrm{G}_{\mathrm{n}}
$$

The last term of Equation (vi) is Io that is dependent on temperature described by equation: 


$$
I_{o @ T}=I_{o @ T r e f} *\left(\frac{T}{\text { Tref }}\right)^{\frac{3}{n}} * e^{-\left[\frac{q^{*} V}{n^{*} k} *\left(\frac{1}{T}-\frac{1}{\text { Tref }}\right)\right]}
$$

\section{III.MPPT}

Maximum Power Point Tracking, frequently referred to as MPPT, is an electronic system that operates the Photovoltaic (PV) modules in a manner that allows the modules to produce all the power they are capable of. MPPT is not a mechanical tracking system that "physically moves" the modules to make them point more directly at the sun.

MPPT is a fully electronic system that varies the electrical operating point of the modules so that the modules are able to deliver maximum available power.

Additional power harvested from the modules is then made available as increased battery charge current.

So this technique is used to improve the efficiency of the solar panel. It is depends on Maximum Power Transfer theorem, the power output of a circuit is maximum when the Thevenin impedance of the circuit (source impedance) matches with the load impedance. Hence our problem of tracking the maximum power point reduces to an impedance matching problem.

In the source side we are using a boost convertor connected to a solar panel in order to enhance the output voltage so that it can be used for different applications like motor load.

By changing the duty cycle of the boost converter appropriately we can match the source impedance with that of the load impedance[7].

\subsection{Different MPPT techniques}

There are different techniques used to track the maximum power point. Few of the most popular techniques are[4]:

1) Perturb and Observe (hill climbing method)

2) Incremental Conductance method

3) Fractional short circuit current

4) Fractional open circuit voltage

5) Neural networks

6) Fuzzy logic

\subsection{Perturb \& Observe Algorithm}

The Perturb \& Observe algorithm states that when the operating voltage of the PV panel is perturbed by a small increment, if the resulting change in power $\Delta \mathrm{P}$ is positive, then we are going in the direction of MPP and we keep on perturbing in the same direction.

If $\Delta \mathrm{P}$ is negative, we are going away from the direction of MPP and the sign of perturbation supplied has to be changed.

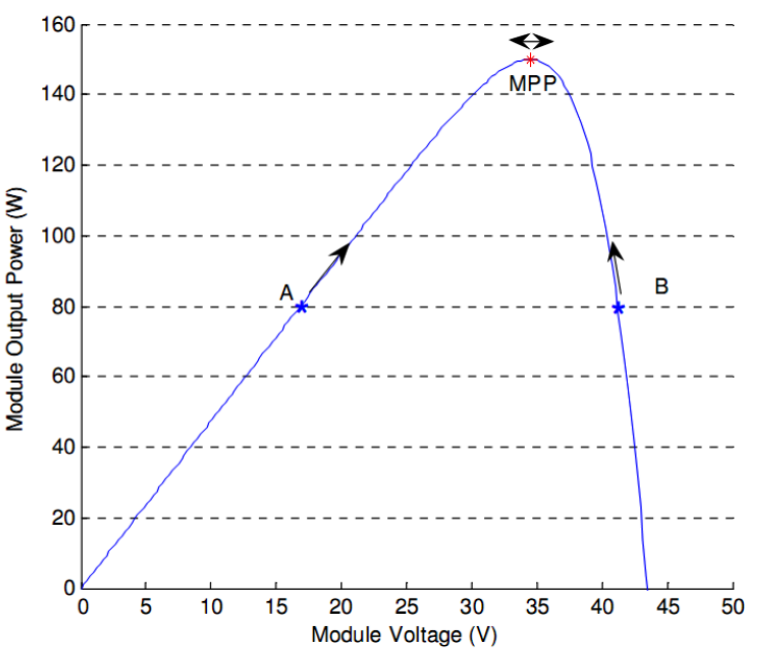

Figure 3.1: Solar panel characteristics showing MPP and operating points $\mathrm{A}$ and $\mathrm{B}$

Figure 3.1 shows the plot of module output power versus module voltage for a solar panel at a given irradiation. The point marked as MPP is the Maximum Power Point, the theoretical maximum output obtainable from the PV panel. Consider A and B as two operating points. As shown in the figure above, the point $\mathrm{A}$ is on the left hand side of the MPP. Therefore, we can move towards the MPP by providing a positive perturbation to the voltage [5]. On the other hand, point $\mathrm{B}$ is on the right hand side of the MPP. When we give a positive perturbation, the value of $\Delta \mathrm{P}$ becomes negative, thus it is imperative to change the direction of perturbation to achieve MPP. The flowchart for the $\mathrm{P} \& \mathrm{O}$ algorithm is shown in Figure 3.2.

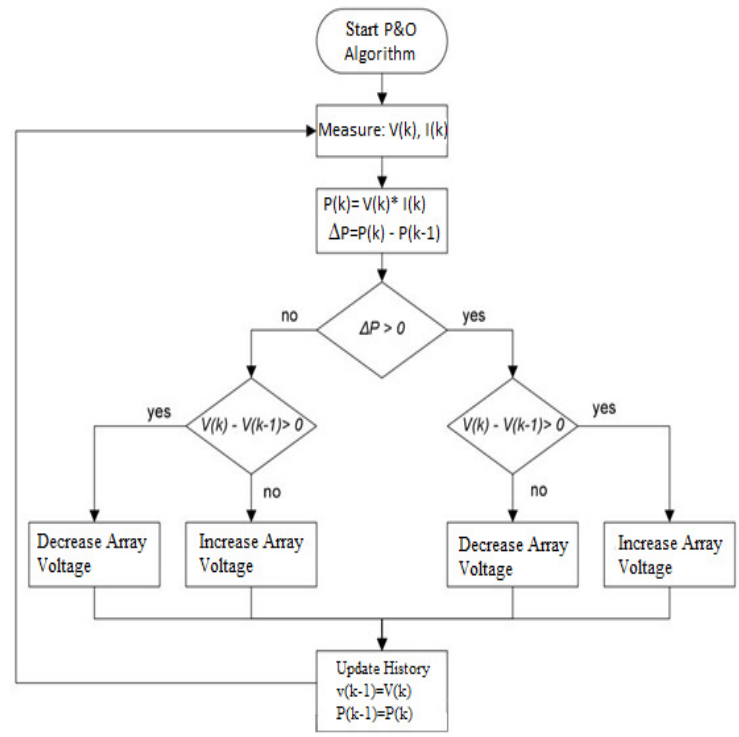

Figure 3.2: Flowchart of Perturb \& Observe algorithm

\section{IV.BuCK BOOST CONVERTER WITH MPPT}

The operating point of the PV panel varies when the load condition varies. The maximum power point may be achieved through appropriate load selection. In most cases, the load is not likely to be optimal (regarding maximum power delivered from the PV panel). Maximum power 
from the PV panel may be attained by incorporating an intelligent mechanism to alter the load resistance observed from the PV panel. Power converters are widely used to adjust operating conditions to attain the maximum power point. Figure 4.1 depicts the incorporation of a buck-boost converter into a PV system. The input voltage is controlled through appropriate adjustments of the duty ratio of the power switches of the converter [8].

Assuming that the buck-boost converter is operating in the continuous conducting mode with $100 \%$ efficiency, the relationship of the voltage and current at the load terminal and those at the PV panel under steady-state conditions are:

$$
V_{o}=\frac{D}{1-D} V_{P V} ; I_{o}=\frac{1-D}{D} I_{P Y}
$$

Based on Ohm's law, the load resistance can be expressed as:

$$
R_{L}=\frac{V_{o}}{I_{o}}=\left(\frac{D}{1-D}\right)^{2} \frac{V_{P V}}{I_{P V}}
$$

Thus, the equivalent resistance observed from the PV panel, denoted as $R P V$, is:

$$
R_{P V}=\frac{V_{P V}}{I_{P V}}=\left(\frac{1-D}{D}\right)^{2} R_{L}
$$

Equation (xi) implies that for a certain load resistance $R L$, the equivalent resistance $R P V$ depends only on the duty ratio of the buck-boost converter. Hence, we may adjust the duty ratio $D$ to achieve maximum power transfer from the PV panel through an optimal mechanism. Figure 4.2 presents the power characteristics of the PV system and power received at the load terminal with different duty ratios for the power switches of the converter. The power developed at the load terminal is:

$$
P_{L}=\frac{V_{o}^{2}}{R_{L}}=\frac{\left(\frac{D}{1-D} V_{P V}\right)^{2}}{R_{L}}=\left(\frac{D}{1-D}\right)^{2} \frac{V_{P V}^{2}}{R_{L}}=\frac{V_{P V}^{2}}{R_{P V}}
$$

The intersection of the PV power curve (blue) and the power curve for the load (red) was the operating point of the PV system [6]. The maximum power point may be achieved by applying the appropriate duty ratio for the power converter. In this study, a fuzzy logic controller was designed to perform the MPPT function.

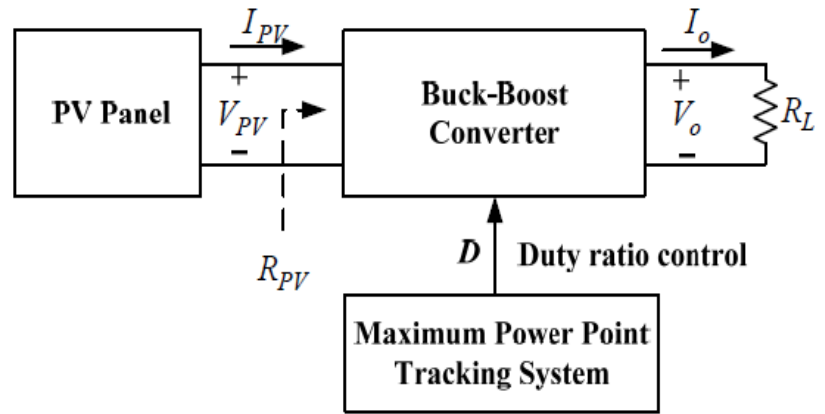

Fig 4.1:PV system with buck-boost converter incorporated

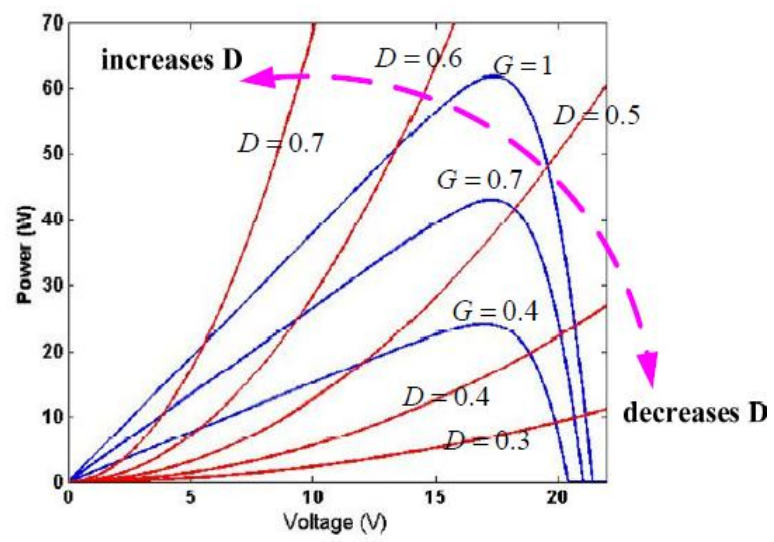

Figure 4.2: Power characteristics of the PV system.

\section{Simulation \& Result}

\section{PV array simulation}

Usually the solar cells are modelled using a specific type of equivalent circuit, a photovoltaic model is based on diode behaviour, which gives to photovoltaic cell its exponential characteristic. In Simulink the solar cell can be modelled with three modelling systems .The solar cell from MATLAB is a solar current source, which includes solar induced current and temperature dependence. This block allows choosing one of two models: a model with 8 parameters in which describes the output current, and a model with 5 parameters if for this equation is applied the following simplifying assumptions: the impedance of the parallel resistor is infinite and the saturation current of the second diode is zero. The model with 5 parameters allows optimization of this block according to the equivalent circuit model parameters or by short circuit current and open circuit voltage. The model shown in Figure 5.1 represents a PV cell array connected to a variable resistor. This resistor has an input ramp which just varies resistance linearly in closed circuit until it reaches the 25 steps [6].

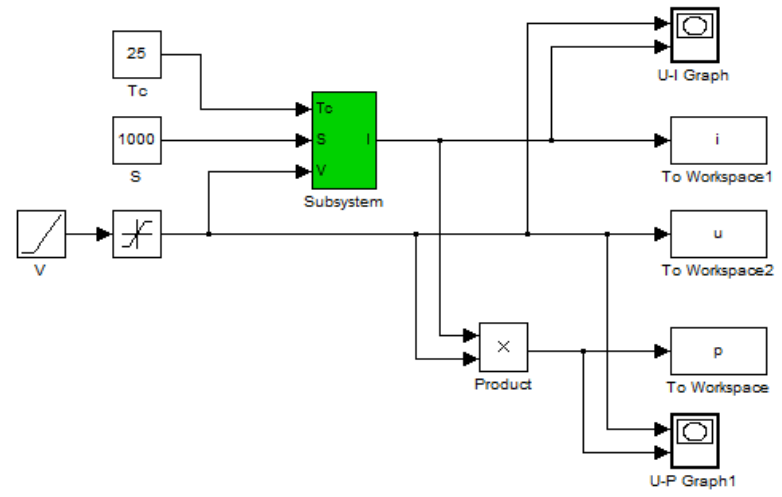

Fig. 5.1: Simulink model of PV array.

The advantage of using this high level of implementation is to create a simple equivalent circuit, which have much more complex parameters, including the effect of temperature in the device which is very important for behaviour of this type of system.

The photovoltaic panel model is validated by simulating at a value of irradiance of $1000 \mathrm{~W} / \mathrm{m} 2$ and a temperature of $25^{\circ} \mathrm{C}$. 
INTERNATIONAL JOURNAL OF INNOVATIVE RESEARCH IN ELECTRICAL, ELECTRONICS, INSTRUMENTATION AND CONTROL ENGINEERING Vol. 3, Issue 3, March 2015

\begin{tabular}{|l|c|}
\hline \multicolumn{1}{|c|}{ Parameter } & Value \\
\hline Short Circuit Current $\quad[\mathrm{A}]$ & $\mathrm{I}_{\mathrm{sc}}=3.12$ \\
\hline Open Circuit Voltage [V] & $\mathrm{V}_{\mathrm{OC}}=1.2$ \\
\hline Quality Factor & $\mathrm{N}=1.5$ \\
\hline Series Resistance $\quad[\mathbf{\Omega}]$ & $\mathrm{R}_{\mathrm{S}}=0$ \\
\hline $\begin{array}{l}\mathbf{1} \text { Order Temp Coefficient for } \\
\mathbf{I}_{\text {ph }}\end{array}$ & $\mathrm{TIPH} 1=0$ \\
\hline Temperature exponent for $\mathbf{R}_{\mathbf{s}}$ & $\mathrm{TRSI}=0$ \\
\hline Parameter Extraction Tem. & $25^{\circ} \mathrm{C}$ \\
\hline Fixed Circuit Temperature & $\mathrm{TFIXED}=$ \\
& $25^{\circ} \mathrm{C}$ \\
\hline
\end{tabular}

I-Parameters of Solar cell in MATLAB Simulink

The V-I and V-P characteristics of the photovoltaic array is given in Figure 5.2 and Figure 5.3. The V-I curve represent the standard behaviour of the photovoltaic cell and photovoltaic array respectively.

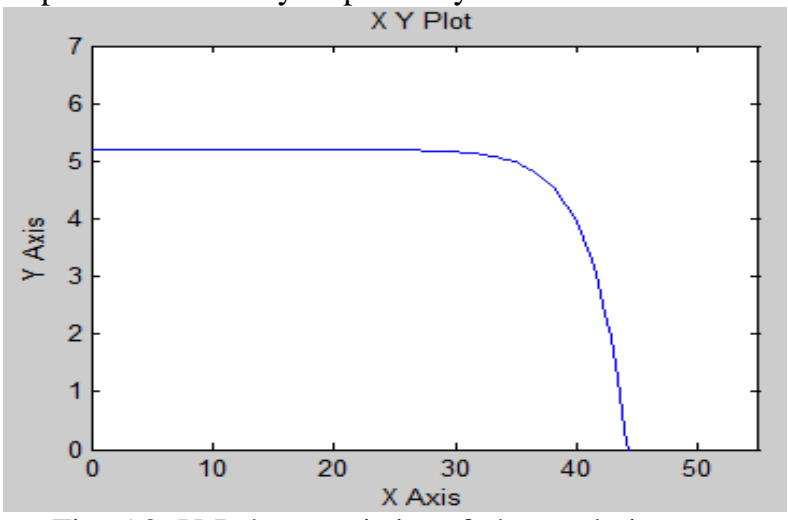

Fig. 5.2: V-I characteristics of photovoltaic array

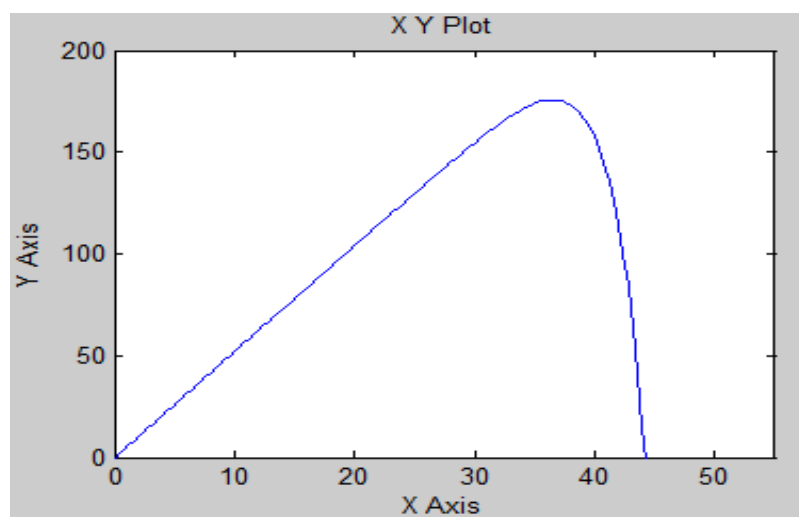

Fig. 5.3: V-P characteristics of the photovoltaic array

Now In fig. 5.4, PV array consists of six PV modules connected in series altogether generating $130 \mathrm{~V}$ dc voltages.

Basically PV module can be implemented as voltage input type PV module or Current input type PV module. In this paper

Current input type PV module is implemented in simulink [14]. The simulink model for single PV module is shown in fig.5.1. PV module parameters are shown in given table

\begin{tabular}{|c|c|c|}
\hline & $\begin{array}{c}\text { PV Array } \\
\text { with MPP }\end{array}$ & $\begin{array}{c}\text { PV Array } \\
\text { without MPP }\end{array}$ \\
\hline $\mathbf{I}_{\mathbf{P V}}$ & $5 \mathrm{~A}$ & $4 \mathrm{~A}$ \\
\hline $\mathbf{V}_{\mathbf{P V}}$ & $104 \mathrm{~V}$ & $113 \mathrm{v}$ \\
\hline PV Energy & $4.08 \mathrm{KWh}$ & $3.64 \mathrm{KWh}$ \\
\hline PV Power & $510.8 \mathrm{~W}$ & $455.2 \mathrm{~W}$ \\
\hline $\begin{array}{c}\text { Ideal PV } \\
\text { Energy }\end{array}$ & $4.08 \mathrm{KWh}$ & $4.08 \mathrm{KWh}$ \\
\hline $\mathbf{E}_{\text {out }}$ & $3.7 \mathrm{KWh}$ & $3.55 \mathrm{KWh}$ \\
\hline
\end{tabular}

Table I: Performance of PV Array system

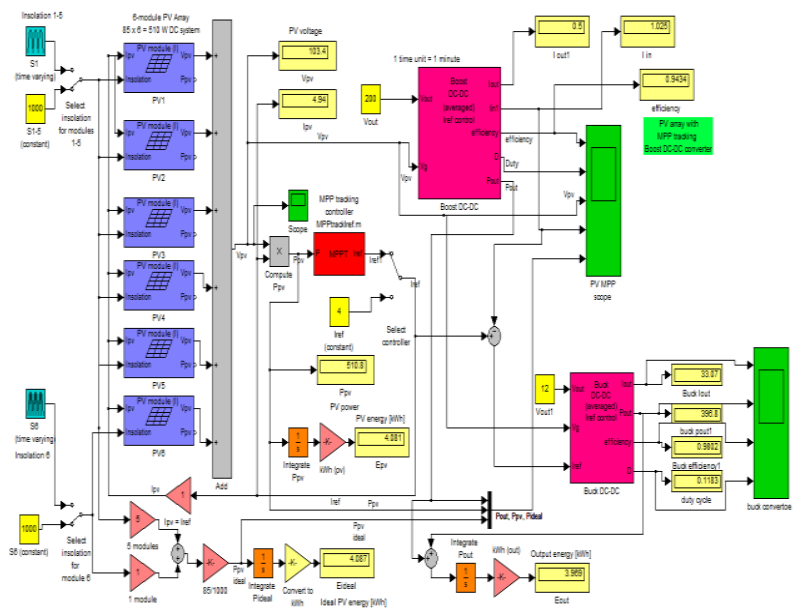

Fig5.4: PV Array connected DC-DC buck boost convertor

\begin{tabular}{|c|c|c|}
\hline & $\begin{array}{c}\text { Boost } \\
\text { Converter }\end{array}$ & $\begin{array}{c}\text { Buck } \\
\text { Convertor }\end{array}$ \\
\hline $\begin{array}{c}\text { Output } \\
\text { Current }\end{array}$ & $0.5 \mathrm{~A}$ & $33 \mathrm{~A}$ \\
\hline Efficiency & 0.94 & 0.98 \\
\hline $\begin{array}{c}\text { Power } \\
\text { Output }\end{array}$ & $100 \mathrm{~W}$ & $397 \mathrm{~W}$ \\
\hline
\end{tabular}

Table II: Output of PV Array system with MPPT

\begin{tabular}{|c|c|c|}
\hline & $\begin{array}{c}\text { Boost } \\
\text { Converter }\end{array}$ & $\begin{array}{c}\text { Buck } \\
\text { Convertor }\end{array}$ \\
\hline $\begin{array}{c}\text { Output } \\
\text { Current }\end{array}$ & $0.5 \mathrm{~A}$ & $28 \mathrm{~A}$ \\
\hline Efficiency & 0.93 & 0.10 \\
\hline Power Output & $100 \mathrm{~W}$ & $0.985 \mathrm{~W}$ \\
\hline
\end{tabular}

Table III: Output of PV Array system without MPPT

The simulation model of the proposed method is shown in Fig.5.4 and the waveforms are shown in fig $5.5 \&$ 5.6. The proposed circuit needs independent dc source which is supplied from photovoltaic cell. The inputs are fed by voltage and current of the PV terminals, while the output provides duty cycle for the buck boost converter. Buck Boost converter controls the output voltage by varying the 
duty cycle $k$, of the switch and the value of $\mathrm{k}$ is 0.67 which is calculated using the formulae $\mathbf{V o}=\mathbf{V s} * \mathbf{k} / \mathbf{1 - k}$. If we vary the pulse width of the pulse generator various voltage ranges at the output can be obtained [15]. Once the buck boost converter injected the power from the pv panel and the controller starts function, it varies the value of duty cycle which will change the input value that is sensed by the MPPT. By using the MPPT the error has been minimized in the system and the efficiency is improved.Table.1. below shows the output values for PV panel.

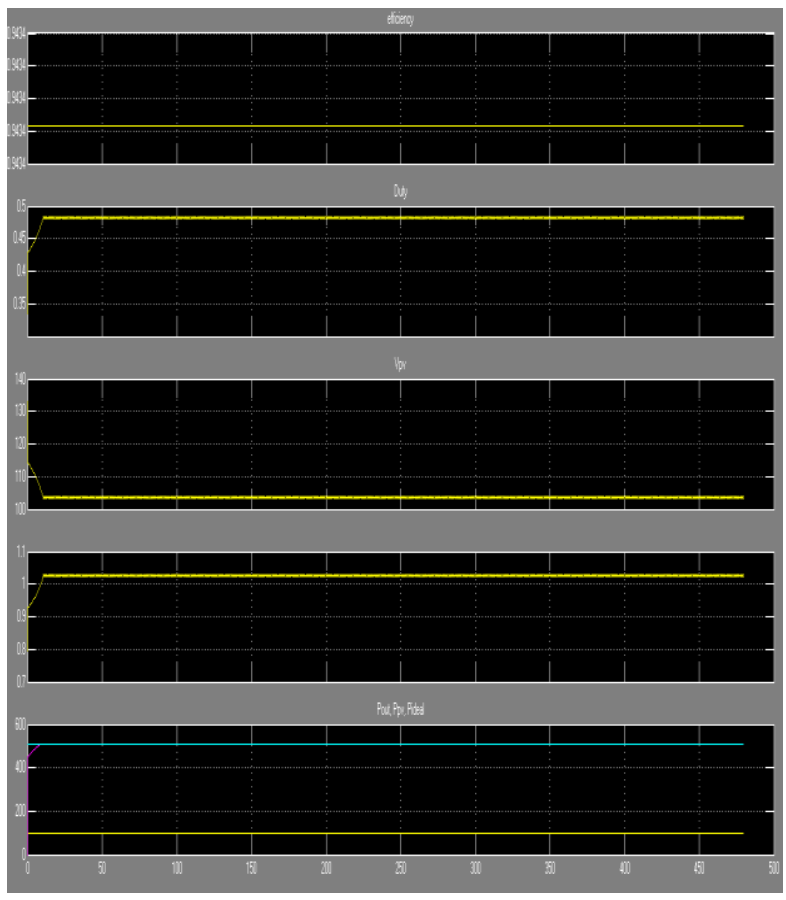

Fig 5.5: Output waveform of PV Array system with M MPPT

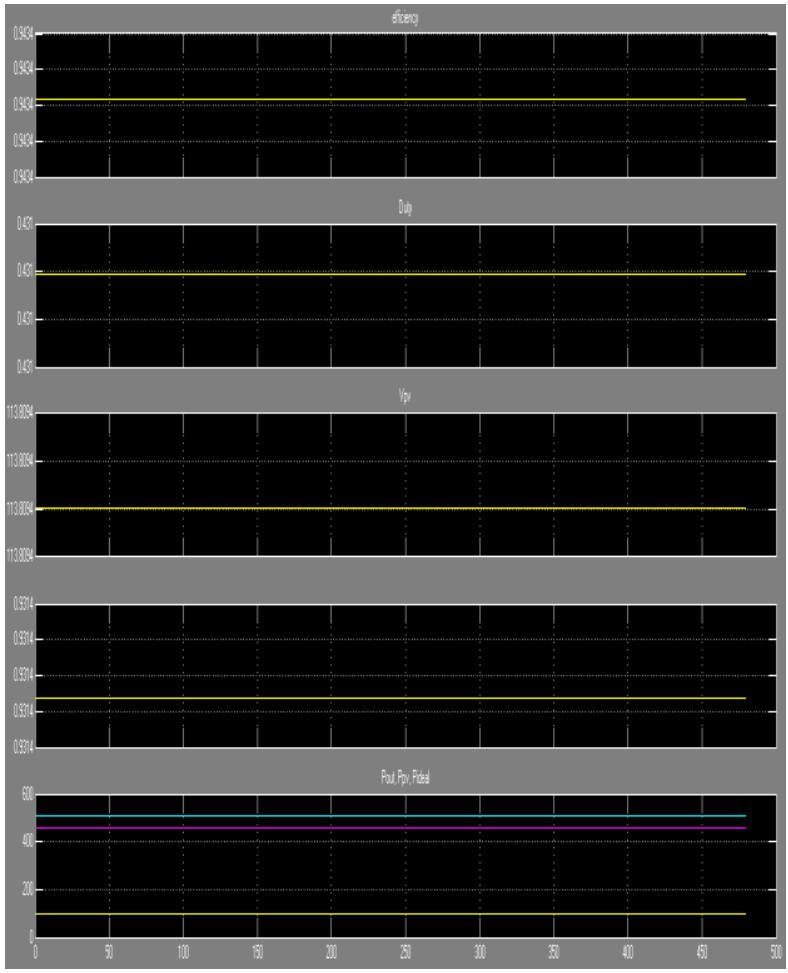

Fig 5.6: Output waveform of PV Array without MPPT

\section{CONCLUSION}

The proposed model is established in SIMULINK software, and output characteristics of photovoltaic array is studied and analysed. Mainly perturb and observation MPPT algorithm is used to obtain the maximum power point of solar array. Buck Boost converter is used to obtain this maximum power point which helps in step down the array voltage to the maximum operating point voltage. So by using MPPT algorithm and buck boost converter solar array is operated at maximum power point irrespective of solar irradiance. Further we can also design the inverter circuit which converts the DC power into AC power. And this can be connected to grid with the help of inverter.

\section{REFERENCES}

[1] Dynamic Modelling and Performance Analysis of a Grid-Connected Current-Source Inverter-Based Photovoltaic System : Prajna Paramita Dash, Student Member, IEEE, and Mehrdad Kazerani, Senior Member, IEEE 2011

[2] Maximum Power Point Tracking For Photovoltaic System by Perturb and Observe Method Using Buck Boost Converter M.S.Sivagamasundar, International Journal of Advanced Research in Electrical, Electronics and Instrumentation Engineering Vol. 2, Issue 6, June 2013

[3] Modeling, Analysis and Neural MPPT Control Design of a PV Generator Powered DC Motor-Pump System; Ahmed. M. Kassem; WSEAS TRANSACTIONS on SYSTEMS, Issue 12, Volume 10, December 2011

[4] Energy comparison of MPPT techniques for PV Systems, ROBERTO FARANDA, WSEAS TRANSACTIONS on POWER SYSTEMS, Issue 6, Volume 3, June 2008

[5] Convergence of pv system with Buck-Boost Converter using MPPT Techniques, Lipika Nanda et. al International Journal Of Engineering And Computer Science November, 2013

[6] Literature survey on maximum power point tracking (mppt) technique for photovoltaic (pv) system, Umesh T. Kute, Preeti S. Ratnaparkhi, IJAREAS Vol. 2 No. 12 December 2013.

[7] Modeling of Maximum Power Point Tracking Algorithm for Photovoltaic Systems, Ioan Viorel Banu,Marcel Istrate "Gheorghe Asachi" Technical University of Iasi.

[8] Comparison of MPPT Algorithms for DC-DC Converters Based PV Systems, A.Pradeep Kumar Yadav, S.Thirumaliah, G.Haritha, IJAREEIE Vol. 1, Issue 1, July 2012.

[9] Modeling \& simulation of a photovoltaic energy system, Sonam mishra, Manju gupta, IJEEER Vol. 3, Issue 1, Mar 2013, 61-66.

[10] Modeling and Simulation of PV Array and its Performance Enhancement Using MPPT (P\&O) Technique, T.Chaitanya, Ch.Saibabu, International Journal of Computer Science \& Communication Networks, Vol 1(1),September-October 2011.

[11] Converter topology for PV system with maximum power point tracking, Shridhar Sholapur, K.R.Mohan, IJSR Vol 3 Issue 5, May 2014.

[12] Mathematical Modelling and Simulation of Photovoltaic Cell using Matlab-Simulink Environment, J. Surya Kumari* and Ch. Sai Babu, IJECE Vol. 2, No. 1, February 2012, pp. 26 34.

[13] Photovoltaic solar cell simulation of shockley diode parameters in matlab, Awodugba, A. O, Sanusi, Y. K., and Ajayi, J. O, International Journal of Physical Sciences Vol. 8(22), pp. 11931200, 16 June, 2013.

[14] A New Technique for Tracking the Global Maximum Power Point of PV Arrays Operating Under Partial-Shading Conditions, Eftichios Koutroulis, Member, IEEE, and Frede Blaabjerg, Fellow, IEEE, IEEE JOURNAL OF PHOTOVOLTAICS, VOL. 2, NO.

[15] Boost Converter Topology for PV System with Perturb And Observe MPPT Algorithm, Shridhar Sholapur et.al, IOSR (Jul Aug. 2014)

\section{BIOGRAPHIES}

Jaya Shukla Belong to UP Received his Bachelor of Technology degree from UNSIET VBSTU, Jaunpur in 2011. Also two years industrial \& teaching experiences.She is pursuing her M.Tech in Electrical Engg. (Power System) from SHIATS, Allahabad, UPIndia.

\footnotetext{
Copyright to IJIREEICE 

Vol. 3, Issue 3, March 2015

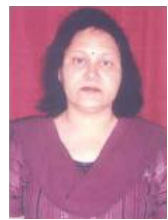

Dr. Jyoti Shrivastava has done her graduation in Electrical Engineering and her post graduation in Design of Heavy Electrical Equipments. At present she is serving as an Senior Assistant Professor in Electrical Engineering department at college of Engineering and Technology, SHIATS, Allahabad, India. She has several international and National papers to her credit. Her field of interest and research are Power system control and operation, power quality improvement and condition monitoring of heavy electrical equipments. Her research aims to increase Transmission \& Distribution system capacity and enhancing system reliability. 